JOURNAL OF SECURITY AND SUSTAINABILITY ISSUES

ISSN 2029-7017 print/ISSN 2029-7025 online

2019 September Volume 9 Number 1

http://doi.org/10.9770/jssi.2019.9.1(22)

Scopus

\title{
SYSTEMATIC RISK AND DETERMINANTS OF COST OF CAPITAL: AN EMPIRICAL ANALYSIS OF SELECTED CASE STUDIES
}

\author{
Hafezali Iqbal Hussain ${ }^{1}$, Herman ${ }^{2}$, Erlane K. Ghani ${ }^{3}$, Mohd Shahril Ahmad Razimi ${ }^{* *}$ \\ ${ }^{1}$ Taylor's Business School, Taylor's University, Malaysia \\ ${ }^{2}$ Management Program, Pakuan University, Indonesia \\ ${ }^{3}$ Faculty of Accountancy, Universiti Teknologi MARA, Malaysia \\ ${ }^{4 *}$ Islamic Business School, Universiti Utara Malaysia, Malaysia \\ E-mails: 4*shahril@uum.edu.my (corresponding author)
}

Received 11 January 2019; accepted 28 June 2019; published 30 September 2019

\begin{abstract}
The objective of this study is to examine the effect of business size, market value of equity, required rate of return, systematic risk, debt ratio and total debt along with inflation on cost of capital for selected firms in five states of ASEAN region. Secondary data is collected during the time of 2000-2017 for ten firms in each country. Findings through regression analysis indicates the fact that significant determinant for fixed payment ratio is required rate of return, size, market to book ratio, systematic risk, and inflation are significant determinant. For interest covered ratio, key determinants are required return, total debt, and market to book ratio, size, and inflation. For dividend payment, size, debt ratio, inflation, and market value of equity. For interest payment, systematic risk, inflation, log market value of equity, size and market to book ratio are found to be significant determinant. These findings are providing a new insight in the literature of finance and financial management. Both theoretical and practical significance of the study can be viewed through provision of literature discussion and empirical findings. Policy makers, financial analysts, and other industry experts can utilize these findings as a meaningful source for strategic decision. However, future studies can be reconsidered remaining countries in ASEAN region and better sample size of the firms.
\end{abstract}

Keywords: cost of capital; required rate of return; inflation; market value of equity; ASEAN

Reference to this paper should be made as follows: Hussain, H.I.; Herman; Ghani, E.K.; Razimi, M.S.A 2019. Systematic risk and determinants of cost of capital: an empirical analysis of selected case studies, Journal of Security and Sustainability Issues 9(1): $295-307$. http://doi.org/10.9770/jssi.2019.9.1(22)

JEL Classifications: F21, E31, G1

\section{Introduction and Background}

From the perspective of corporate finance, concept of risk for the payment of fixed cost like interest and dividend are under significant attention by the reserachers. Growing body of literature is presented, covering the title of risk in the form of fixed payment obligations and overall business growth is provided in both developed and emerging economies. Meanwhile business performance is highly associated to its cost of capital like interest payment and dividend payments. Both performance and cost of debt and cost of equity indicates the fact that firms can get strategic benefits while creating reasonable tradeoff between the both (Botosan, 1997; Gitman, Juchau, \& Flanagan, 2015; Khan \& Jain, 1992; Linsley, Shrives, \& Crumpton, 2006; Artha \& Mulyana, 2018; Schwarz, 2018; Mokhova et al., 2018).

For deciding an appropriate financial structure, cost of capital is assumed to be a critical factor as described by earlier reserachers (Bontis, 2001; De Jong, Kabir, \& Nguyen, 2008; Gertler, 1988; Rajan \& Zingales, 1995; Aregbeyen \& Fasanyan, 2017, Masood et al., 2019). Meanwhile, lot of studies have explained the factors asso- 
ciated to the capital structure of the business. Among several debt ratio is found to be most important, reflected through total debt over total assets (Bevan \& Danbolt, 2002; Van der Wijst \& Thurik, 1993; Ali \& Harvie, 2015). To summarize overall cost of capital, the idea of weighted average cost of capital covers the interest bearing and liabilities being captured by the business (Arditti \& Levy, 1977; Bacidore, Boquist, Milbourn, \& Thakor, 1997; Baker \& Wurgler, 2015; Miles \& Ezzell, 1980; Abdulrasheed, 2017). Investors from the market place provides the portion of equity capital to finance the capital investment of the business. Such financing is in the form of common stock and preferred stock. However, preferred stock is found to has lower portion in the balance sheet, comparatively to common stock equity (Flannery, 2016; Akhir et al. 2018; Hussain, Grabara, Razimi, \& Sharif, 2019). The cost of equity portion is reflected in the form of dividend payment to the shareholders over regular intervals.

In addition, for debt portion in the balance, fixed cost is observed in the form of interest payments through operating profit (Foster \& Kalev, 2016; Gitman et al., 2015; Aldulaimi \& Abdeldayem, 2018). The purpose of this study is to examine the effect size, debt ratio, inflation, size, and systematic risk, required rate of return and market value of equity on various factors considered as capital cost in ASEAN region. The rest of the study is as follows. Section two shows literature review. Section three defines variables. Section four and five indicates the samples, methods and findings of the study. Last section covers conclusion of the study.

\section{Literature Review}

Various studies have explored the key factors affecting the capital cost in different regions. For instance, (Boutayeba, 2017) have examined the various determinants of cost of capital for emerging industries of Egypt and middle east region. An empirical analysis have been performed based on the sample firms of 119 companies. Both book and market-based measures to equity and overall cost of capital is calculated. It is found that overall cost of capital is 12 percent while cost of equity is 12.5 percent. To get significant findings, stepwise multiple regression technique is applied. The factors like growth and size are found to be significant indicator of cost of capital. Meanwhile for trading companies, financial and business risk factors are key determinants of cost of capital. In real estate, cost of capital is higher. Meanwhile, the factor of liquidity can not be ignored to analyze its effect of cost of capital (Haseeb et al, 2019; Mira et al., 2019).

Rand, 2007; Brown \& Ibekwe, 2018 examines the cost of capital and credit constraints and key factors which restrict the manufacturing firms for getting loan facilities from financial market of Vietnam. While using the information through enterprise survey, his study indicates the fact that debt holing of the business can increase between 40 to 115 percent if various constraints for the burrowing the loan. Meanwhile, it is found that business enterprise have not enough time to get rid from administrative difficulties. Besides, larger interest rates are linked to those loans which are under the title of collateral and securities. Liu and Wysocki (2017) focus on the cross-sectional determinants of cost of capital measures. For this purpose, they have examined the empirical association between accrual quality and cost of capital. At first, they have found that accrual quality and operating volatility of the business are key determinants. Their findings are found to be empirical addition in the literature work, involving the factors like accrual quality, operating variation of the business and cost of capital.

Drobetz, El Ghoul, Guedhami, and Janzen (2018) examine the factor of investment, policy uncertainty and cost of capital. For this purpose, economic policy is observed as key indicator between investment and cost of capital. They have found that negative relationship exists between cost of capital and investment. However, it is observed that increasing the uncertainty in economic policy lowers the investment sensitivity for those firms which are working as government subsidizes. It is concluded that economic policy and uncertainty can significantly disturb the relationship between cost of capital and investment.

Belkhir, Saad, and Samet (2018) examine the extreme liquidity of the stock and cost of capital. For this purpose, a sample of 45 countries is examined through robust analysis. It is observed that those business firms having extreme value of liquidity are facing higher cost of capital. Meanwhile, it is observed that one standard 
deviation increases in the value of liquidity causing a shift of 30 basis points in the value of cost of capital. Meanwhile, this association between high liquidity and cost of capital is observed higher at the time when there is downturn in the market and presence of more volatility. Some other studies have also explored the factor of cost of capital through various determinants. For example, (Huizinga, Voget, \& Wagner, 2012; Abosedra \& Sita, 2018) explores the capital gains, taxation and cost of capital, (Kwabi, Boateng, \& Adegbite, 2018) for trading laws \& cost of capital, (Gupta, Krishnamurti, \& Tourani-Rad, 2018) for corporate governance, financial development and cost of capital. In addition, (Boubakri, Guedhami, Mishra, \& Saffar, 2012; Adegbite, 2017) indicates the relationship between political connection for the cost of capital in the form of equity. Some other empirical work is not neglectable to explore the idea of cost of capital Notables are (Anderson, Mansi, \& Reeb, 2003, 2004; Sengupta, 1998) for the cost of debt capital, (Antoniou, Doukas, \& Subrahmanyam, 2015; Berger, Chen, \& Li, 2018; Botosan, 1997; Botosan \& Plumlee, 2002; Cao, Myers, Tsang, \& Yang, 2017; Dhaliwal, Judd, Serfling, \& Shaikh, 2016; Dhaliwal, Li, Tsang, \& Yang, 2011; Hail \& Leuz, 2006; Mazzi, André, Dionysiou, \& Tsalavoutas, 2017; Miller \& Modigliani, 1958; Richardson \& Welker, 2001). To the best of author's findings this study is a very first contribution, examining the effect of size, systematic risk, inflation, debt portion, market value of equity for the various firms in ASEAN region. Earlier studies have ignored the ASEAN region for the cost of capital and its key determinants through empirical analysis.

\section{Measurement of Variables}

Definition and measurement of variables are presented in Table 1.

Table 1. Definition and Measurement of Variables

\begin{tabular}{|c|c|c|c|}
\hline $\begin{array}{l}\text { Name of } \\
\text { Variable }\end{array}$ & Abbreviations & Definition & Measurement \\
\hline $\begin{array}{l}\text { Fixed Payment } \\
\text { Covered Ratio }\end{array}$ & FPCR & $\begin{array}{c}\text { Indicates the firm's ability to pay both type of fixed } \\
\text { payments eight debt or equity through its operating profit }\end{array}$ & $\begin{aligned} & \text { EBIT/interest expense } \\
+ & \text { preferred stock dividend }\end{aligned}$ \\
\hline $\begin{array}{l}\text { Interest Covered } \\
\text { Ratio }\end{array}$ & ICR & $\begin{array}{l}\text { Indicate the firm's ability to pay its interest } \\
\text { payment through operating profit }\end{array}$ & $\mathrm{EBIT} /$ interest payment \\
\hline $\begin{array}{l}\text { Dividend Payout } \\
\text { Ratio }\end{array}$ & DIVIDENDPR & $\begin{array}{l}\text { It indicates the dividend payment capacity } \\
\text { through net income of the business }\end{array}$ & Dividend paid/net income \\
\hline Interest payment & INTERESTP & Reflects overall interest payment by the business in a year & Annual interest payment \\
\hline Size & SIZE & Shows the growth of the business through its assets & Total assets of the business \\
\hline $\begin{array}{l}\text { Market to Book } \\
\text { Ratio }\end{array}$ & M2BRATIO & $\begin{array}{l}\text { Measures the risk and return of the business through } \\
\text { comparing market value of share to its book value }\end{array}$ & $\begin{array}{l}\text { Market value per share/book } \\
\text { value per share }\end{array}$ \\
\hline $\begin{array}{l}\text { Required Rate } \\
\text { of Return }\end{array}$ & RROR & Indicates the overall return required by the investor & $\begin{array}{l}\text { Measure through risk free } \\
\text { return + market risk premium }\end{array}$ \\
\hline Beta & BETA & Measures the systematic risk in the investment & $\begin{array}{l}\text { Change in asset return/change } \\
\text { in market return }\end{array}$ \\
\hline Inflation & INF & Gradual increase in the prices of goods and services & Annual consumer price index \\
\hline Debt Ratio & DEBTRATIO & Measures the portion of debt in total assets & Total Debt/Total assets \\
\hline Total Debt & TDEBT & Overall debt portion in the balance sheet & $\begin{array}{l}\text { Annual Total debt in } \\
\text { balance sheet }\end{array}$ \\
\hline Total Equity & LOGMVALUEO Y & Reflects the equity portion for the business & $\begin{array}{l}\text { Log value of market } \\
\text { value of equity }\end{array}$ \\
\hline
\end{tabular}

\section{Sample and Methods}

This study has considered secondary data technique during the time of 2010 to 2017. Five states from ASEAN region including Brunei, Malaysia, Indonesia, Thailand and Singapore are selected. 10 business firms from each region is selected under sample period of interest, while data is collected through web sources of the company, data stream and annual reports. After the data collection, both descriptive and separate regression analysis have been conducted for each region, which provides better understanding of data trends and causal association between the variables. 


\section{Results and Discussion}

Descriptive findings for the business firms working in the region of Brunei are presented under Table 2. Mean score for fixed payment covered ratio as first dimension of cost of both capital; debt and equity is 1.208. Minimum ratio for FPC is .326 and maximum is 6.71 . for interest covered ratio as $2^{\text {nd }}$ dimension of cost of capital is 6.002 with the deviation of .477 for dividend payout ratio as cost of equity capital is 1.86 for overall interest payment, an average amount for the firm's working in Brunei is 3590 BND. As per the size of the firm, average amount of 10600 in BND is observed. For market to book ratio an average score is 7.20 with the deviation from the mean is 1.05 for required rate of return mean score is 4.428 with the deviation of 1.22. As per the findings for systematic risk (Beta), overall trend for selected firms in Brunei is .646. For inflation an average trend of .389 is observed. While debt ratio has a deviation from the mean is .901. In addition, log of market value of equity is 4.32 . For total debt it is 8.97 percent as per natural log.

Table 2. Descriptive Statistics Manufacturing Firms in Brunei

\begin{tabular}{|c|c|c|c|c|c|}
\hline Variable & Obs & Mean & Std.Dev. & Min & Max \\
\hline FPCR & 67 & 1.675 & 1.208 & .326 & 6.711 \\
\hline ICR & 67 & 6.002 & .477 & 5.445 & 7.048 \\
\hline DIVIDENDPR & 60 & 1.865 & .868 & .5 & 4 \\
\hline INTERESTP & 68 & 3590 & 4.41 & 1621 & 16668 \\
\hline SIZE & 68 & 10600 & 15.20 & 7230 & 13170 \\
\hline M2BRATIO & 68 & 7.20 & 1.05 & 2.187 & 9.652 \\
\hline RROR & 68 & 4.428 & 1.229 & 2.05 & 12.34 \\
\hline BETA & 67 & .646 & .174 & .4 & 1.03 \\
\hline INF & 65 & .389 & .796 & -.48 & .74 \\
\hline DEBTRATIO & 62 & .52 & .901 & -.74 & .58 \\
\hline LOGMVALUEO $\sim Y$ & 63 & 4.32 & 1.253 & 3 & 6 \\
\hline TDEBT & 65 & 8.97 & 1.50 & 1.202 & 5.85 \\
\hline
\end{tabular}

Table 3 reflects the findings for first four regression models for the factor like fixed payment covered ratio, interest covered ratio, dividend payout ratio, and finally overall interest payment. It is observed that required rate of return for the firms in Burnie is significantly and negatively affecting the interest covered ratio, and dividend payout ratio with the coefficient of -.008 and -.003 at 5 percent and 1 percent respectively. Meanwhile, through higher debt ratio, significant and positive influence on dividend payout ratio is observed with the coefficient of .252 and standard error of .0169. Market value of equity through its log conversion indicates a significant but negative influence on DPR. For total debt, effect on interest covered ratio or ICR is 1.27, significant at 1 percent. For model three of DPR, highest explanatory variation is observed; 94.5. This value implies that overall high robust variation in DPR is explained by all the regressors of the model.

Table 3. Regression Findings for Manufacturing Firms In Brunei

\begin{tabular}{|c|c|c|c|c|}
\hline & $(1)$ & $(2)$ & $(3)$ & $(4)$ \\
\hline VARIABLES & FPCR:BRUNEI & ICR:BRUNEI & DPR:BRUNEI & INTP:BRUNEI \\
\hline SIZE & $-6.11 \mathrm{e}-08$ & $-1.95 \mathrm{e}-08$ & $2.40 \mathrm{e}-08$ & -0.0188 \\
\hline & $(1.24 \mathrm{e}-07)$ & $(2.97 \mathrm{e}-08)$ & $(3.12 \mathrm{e}-08)$ & $(0.0354)$ \\
\hline M2BRATIO & $-2.85 \mathrm{e}-08$ & $-1.31 \mathrm{e}-09$ & $-1.13 \mathrm{e}-08$ & 0.00409 \\
\hline RROR & $(7.16 \mathrm{e}-08)$ & $(1.12 \mathrm{e}-08)$ & $(9.67 \mathrm{e}-09)$ & $(0.0331)$ \\
\hline & $-0.0118^{*}$ & $-0.00884 * *$ & $-0.00300 * * *$ & $(700.0)$ \\
\hline BETA & $(0.00603)$ & $(0.00392)$ & $(0.00109)$ & 56,061 \\
\hline
\end{tabular}




\begin{tabular}{|c|c|c|c|c|}
\hline INF & -0.147 & -0.488 & 0.163 & $-113,947$ \\
\hline & $(0.926)$ & $(0.477)$ & $(0.205)$ & $(259,503)$ \\
\hline DEBTRATIO & 0.0916 & 0.0130 & $0.252 * * *$ & 13,626 \\
\hline & $(0.0767)$ & $(0.0303)$ & $(0.0169)$ & $(11,576)$ \\
\hline LOGMVALUEOFEQUITY & -0.669 & 0.246 & $-0.624 * *$ & $-12,724$ \\
\hline & $(1.500)$ & $(0.700)$ & $(0.276)$ & $(315,035)$ \\
\hline TDEBT & $2.08 \mathrm{e}-08$ & $1.27 \mathrm{e}-08 * * *$ & $-8.57 \mathrm{e}-10$ & 0.00607 \\
\hline Constant & $(2.19 \mathrm{e}-08)$ & $(3.62 \mathrm{e}-09)$ & $(2.98 \mathrm{e}-09)$ & $6.00665)$ \\
\hline & 1.154 & $9.059 * *$ & 0.613 & $(1.518,193$ \\
\hline Observations & $(6.080)$ & $(3.406)$ & $654 \mathrm{e}+06)$ \\
\hline R-squared & 70 & 0.242 & 65 & 6.945 \\
\hline
\end{tabular}

Robust standard errors in parentheses

$* * * \mathrm{p}<0.01, * * \mathrm{p}<0.05, * \mathrm{p}<0.1$

Table 4 presents the descriptive findings for Indonesian firms under sample period of interest. for FPCR mean score is 1.48 with the deviation of 1.19 for ICR, average value is 6.187 and for dividend payout ratio is 1.789 . For the payment of overall interest as cost of debt capital, average amount is 2256 INDR. For the size of firms, overall value is 46800 INDR.

Table 4. Descriptive Statistics For Indonesian Firms

\begin{tabular}{|c|c|c|c|c|c|}
\hline Variable & Obs & Mean & Std.Dev. & Min & Max \\
\hline FPCR & 70 & 1.498 & 1.199 & .089 & 4.892 \\
\hline ICR & 69 & 6.187 & .652 & 5.066 & 7.646 \\
\hline DIVIDENDPR & 69 & 1.786 & .795 & .635 & 4.36 \\
\hline INTEREST & 70 & 2256 & 5.01 & 3366 & $1.07 \mathrm{e}+07$ \\
\hline SIZE & 63 & 46800 & 1.03 & 10728 & 59720 \\
\hline M2BRATIO & 65 & 2.85 & 5.62 & 1.9857 & 1.880 \\
\hline RROR & 68 & 8.57 & 4.648 & 1.05 & 11.66 \\
\hline BETA & 68 & .619 & .179 & .36 & .98 \\
\hline INF & 69 & 6.784 & .891 & 5.44 & 8.32 \\
\hline DEBTRATIO & 70 & 7.06 & 2.773 & 3 & 13 \\
\hline LOGMVALUEO Y & 68 & 4.16 & 1.017 & 3 & 6 \\
\hline
\end{tabular}

For the business firms working in the region of Indonesia, regression findings are presented under Table 5. It is found that size has its significant and positive impact on the value of fixed payment covered ratio. While market to book ratio ind9icates a significantly positive influence on both FPCR and interest covered ratio. It is implied that more fixed and interest covered ratio for both sources of capital is observed through market to book ratio of ordinary shares. For systematic risk in terms of beta, significant and negative influence of 1.740 is observed. Meanwhile level of inflation is also causing a significant and increasing impact on value of interest payment. It means higher the inflation in the economy of Indonesia, more payment of interest over debt. Through market value of equity, significant and positive influence is observed over interest payment. While explanatory power under model 3 for Indonesia business firm is 96.3 and for model 4 it is 98.2 reflecting higher change in dividend payout ratio and interest payment (Table 5). 
Table 5. Regression findings for Indonesian Firms

\begin{tabular}{|c|c|c|c|c|}
\hline & $(1)$ & $(2)$ & (3) & (4) \\
\hline VARIABLES & FPCR:INDONESIA & ICR:INDONESIA & DPR:INDONESIA & INTP:INDONESIA \\
\hline \multirow[t]{2}{*}{ SIZE } & $4.92 \mathrm{e}-08^{*}$ & $1.48 \mathrm{e}-08$ & $4.85 \mathrm{e}-09$ & 0.0460 \\
\hline & $(2.76 \mathrm{e}-08)$ & $(1.09 \mathrm{e}-08)$ & $(9.03 e-09)$ & $(0.0323)$ \\
\hline \multirow[t]{2}{*}{ M2BRATIO } & $1.59 \mathrm{e}-07 * * *$ & $8.30 \mathrm{e}-08 * * *$ & $1.07 \mathrm{e}-08$ & 0.0679 \\
\hline & $(5.77 \mathrm{e}-08)$ & $(2.58 \mathrm{e}-08)$ & $(1.03 \mathrm{e}-08)$ & $(0.0432)$ \\
\hline \multirow[t]{2}{*}{ RROR } & 0.00154 & 0.000428 & -0.000206 & -777.3 \\
\hline & $(0.00113)$ & $(0.000475)$ & $(0.000265)$ & $(972.0)$ \\
\hline \multirow[t]{2}{*}{ BETA } & -7.835 & -0.585 & 1.335 & $-1.740 \mathrm{e}+07 * * *$ \\
\hline & $(9.477)$ & $(3.827)$ & $(2.637)$ & $(5.452 \mathrm{e}+06)$ \\
\hline \multirow[t]{2}{*}{ INF } & 0.0624 & 0.510 & 0.226 & $1.919 * *$ \\
\hline & $(1.160)$ & $(0.477)$ & $(0.306)$ & $(0.092)$ \\
\hline \multirow[t]{2}{*}{ DEBTRATIO } & 0.0140 & -0.0193 & $0.244 * * *$ & $-7,450$ \\
\hline & $(0.0730)$ & $(0.0298)$ & $(0.0140)$ & $(2.930)$ \\
\hline \multirow[t]{2}{*}{ LOGMVALUEOFEQUITY } & 1.116 & 0.000941 & -0.583 & $2.752 * * *$ \\
\hline & $(1.414)$ & $(0.576)$ & $(0.403)$ & $(0.801)$ \\
\hline \multirow[t]{2}{*}{ TDEBT } & $-4.85 e-09$ & $-5.57 e-09$ & -0 & 0.0229 \\
\hline & $(1.55 \mathrm{e}-08)$ & $(8.85 \mathrm{e}-09)$ & $(4.21 \mathrm{e}-09)$ & $(0.0149)$ \\
\hline \multirow[t]{2}{*}{ Constant } & 2.413 & 4.066 & 0.171 & $1.221 \mathrm{e}+07 * * *$ \\
\hline & (7.761) & (3.094) & $(2.011)$ & $(4.148 \mathrm{e}+06)$ \\
\hline Observations & 68 & 69 & 62 & 67 \\
\hline R-squared & 0.336 & 0.632 & 0.963 & 0.982 \\
\hline
\end{tabular}

Robust standard errors in parentheses

$* * * \mathrm{p}<0.01, * * \mathrm{p}<0.05, * \mathrm{p}<0.1$

For descriptive findings of Malaysian firms, Table 6 reflects the mean score, deviation from the mean, minimum and maximum values. Regression findings are presented under table 7. It is found that for dividend payout ratio, debt ratio has its significant and positive influence with the coefficient of .234 and standard error of .0127 respectively. Through market value of equity, DPR has a significant but negative influence of -.797 with error of .259. the rest of the indicators for cost of capital for Malaysian firm is insignificant. As per explained variation, market value of equity is creating 94.7 percent variation in DPR and 82.9 percent is observed for interest payment through SIZE.

Table 6. Descriptive Statistics for Malaysian Firms

\begin{tabular}{|c|c|c|c|c|c|}
\hline Variable & Obs & Mean & Std.Dev. & Min & Max \\
\hline FPCR & 62 & 1.4 & 1.226 & .038 & 4.847 \\
\hline ICR & 68 & 6.666 & .289 & 6.165 & 7.157 \\
\hline DIVIDENDPR & 62 & 2.033 & 1.096 & .5 & 4.33 \\
\hline INTERESTP & 63 & 6854 & 17.012 & 3572 & 8920 \\
\hline SIZE & 62 & 8530000 & $1.60 \mathrm{e}+07$ & 16778 & $6.46 \mathrm{e}+07$ \\
\hline M2BRATIO & 61 & 1.53 & 2.43 & .631 & 3.650 \\
\hline RROR & 65 & .861 & .479 & .12 & 2.86 \\
\hline BETA & 65 & .658 & .218 & .36 & 1.1 \\
\hline INF & 62 & 6.892 & .829 & 5.43 & 8.34 \\
\hline DEBTRATIO & 63 & 8.25 & 3.582 & 3 & 13 \\
\hline LOGMVALUEO $\sim$ Y & 65 & 4.438 & 1.236 & 3 & 6 \\
\hline TDEBT & 68 & $1.56 \mathrm{e}+07$ & $2.52 \mathrm{e}+07$ & 174000 & $1.03 \mathrm{e}+08$ \\
\hline
\end{tabular}


Table 7. Regression Findings for Manufacturing Firms in Malaysia

\begin{tabular}{|c|c|c|c|c|}
\hline & (1) & $(2)$ & (3) & (4) \\
\hline VARIABLES & FPCR:MALAYSIA & ICR:MALAYSIA & DPR:MALAYSIA & INTP:MALAYSIA \\
\hline \multirow[t]{2}{*}{ M2BRATIO } & $-3.14 \mathrm{e}-08$ & $7.24 \mathrm{e}-09$ & $4.10 \mathrm{e}-09$ & -0.00256 \\
\hline & $(3.76 \mathrm{e}-08)$ & $(7.75 \mathrm{e}-09)$ & $(1.36 \mathrm{e}-08)$ & $(0.0310)$ \\
\hline \multirow[t]{2}{*}{ RROR } & -0.245 & 0.0173 & 0.108 & $-166,723$ \\
\hline & $(0.446)$ & $(0.0936)$ & $(0.137)$ & $(238,185)$ \\
\hline \multirow[t]{2}{*}{ BETA } & -0.961 & 0.685 & 2.300 & $-3.747 e+06$ \\
\hline & $(3.687)$ & $(1.352)$ & $(1.691)$ & $(4.273 \mathrm{e}+06)$ \\
\hline \multirow[t]{2}{*}{ INF } & 0.729 & -0.0975 & 0.304 & $-583,921$ \\
\hline & $(0.528)$ & $(0.191)$ & $(0.225)$ & $(694,643)$ \\
\hline \multirow[t]{2}{*}{ DEBTRATIO } & 0.0268 & -0.0198 & $0.234 * * *$ & 3,024 \\
\hline & $(0.0636)$ & $(0.0132)$ & $(0.0127)$ & $(40,075)$ \\
\hline \multirow[t]{2}{*}{ LOGMVALUEOFEQUITY } & 0.312 & -0.0635 & $-0.797 * * *$ & 597,417 \\
\hline & $(0.609)$ & $(0.200)$ & $(0.259)$ & $(726,886)$ \\
\hline \multirow[t]{2}{*}{ SIZE } & $4.36 \mathrm{e}-08$ & $-5.06 e-09$ & $-7.98 \mathrm{e}-09$ & $0.0526^{*}$ \\
\hline & $(3.33 \mathrm{e}-08)$ & $(7.02 \mathrm{e}-09)$ & $(1.28 \mathrm{e}-08)$ & $(0.0272)$ \\
\hline \multirow[t]{2}{*}{ TDEBT } & $-5.78 \mathrm{e}-08$ & $7.53 \mathrm{e}-09$ & $-4.13 e-10$ & 0.0199 \\
\hline & $(5.85 \mathrm{e}-08)$ & $(1.32 \mathrm{e}-08)$ & $(1.80 \mathrm{e}-08)$ & $(0.0794)$ \\
\hline \multirow[t]{2}{*}{ Constant } & -3.867 & $7.190 * * *$ & -0.0135 & $3.785 \mathrm{e}+06$ \\
\hline & $(3.193)$ & $(1.334)$ & $(1.477)$ & $(3.941 \mathrm{e}+06)$ \\
\hline Observations & 68 & 62 & 68 & 3 \\
\hline R-squared & 0.394 & 0.334 & 0.947 & 0.829 \\
\hline
\end{tabular}

Robust standard errors in parentheses

$* * * \mathrm{p}<0.01, * * \mathrm{p}<0.05, * \mathrm{p}<0.1$

Table 8 indicates the effect of selected explanatory variables on various items of cost of both debt and equity capital in the region of Malaysia. It is observed that effect of $\log$ for market value of equity has its significant and negative influence on dividend payout ratio with the coefficient of .-.797 and standard error of .259 while through debt ratio effect on DPR is .234 and standard error of -.0127. In addition, effect of size on interest payment is .0526, indicating significantly positive influence on it. The rest of the variables are found to be insignificant for all factors of cost of capital in Malaysian firms.

Table 8. Descriptive Statistics for Manufacturing Firms in Thailand

\begin{tabular}{|c|c|c|c|c|c|}
\hline Variable & Obs & Mean & Std.Dev. & Min & Max \\
\hline FPCR & 68 & 1.748 & 1.568 & .068 & 6.79 \\
\hline ICR & 70 & 6.009 & .543 & 5.282 & 7.599 \\
\hline DIVIDENDPR & 69 & 1.88 & .857 & .5 & 4.33 \\
\hline INTERESTP & 68 & 10700 & 9.354 & 2778 & 15324 \\
\hline SIZE & 68 & 4390000 & 6.3687 & 10440 & $2.38 \mathrm{e}+07$ \\
\hline M2BRATIO & 59 & $1.38 \mathrm{e}+07$ & $3.28 \mathrm{e}+07$ & 151000 & $1.67 \mathrm{e}+08$ \\
\hline RROR & 62 & 12.479 & 24.344 & .02 & 139.47 \\
\hline BETA & 69 & .672 & .192 & .36 & 1.16 \\
\hline INF & 69 & 6.974 & .989 & 5.19 & 8.54 \\
\hline DEBTRATIO & 68 & 8.122 & 3.066 & 3 & 13 \\
\hline LOGMVALUEO $\sim$ Y & 67 & 4.592 & 1.117 & 3 & 6 \\
\hline TDEBT & 63 & $1.44 \mathrm{e}+08$ & $2.76 \mathrm{e}+08$ & 2432 & $1.10 \mathrm{e}+09$ \\
\hline
\end{tabular}


For the business firms working in the region of Thailand, effect of size on interest covered ratio and overall interest payment is significant and positive with the coefficient of 4.55 and .242 respectively, while, market to book ratio indicates an effect of .0809 on interest payment. It is observed that required rate of return RROR is highly and significantly affecting interest payment in Thailand. It means increasing required return indicates its direct influence on interest payments in Thailand. Through systematic risk or Beta, fixed payment covered ratio has a positive effect of 15.50 with standard error of 6.870 . While more inflation in the economy is leading towards more dividend payout ratio. Through debt ratio, DPR has a significant and positive influence with the coefficient of .229 (Table 9, Table 10).

Table 9. Regression Findings for Manufacturing Firms in Thailand

\begin{tabular}{|c|c|c|c|c|}
\hline & (1) & (2) & (3) & (4) \\
\hline VARIABLES & FPCR:THAILAND & ICR:THAILAND & DPR:THAILAND & INTP:THAILAND \\
\hline \multirow[t]{2}{*}{ SIZE } & $3.52 \mathrm{e}-09$ & $4.54 \mathrm{e}-08^{* * *}$ & $-2.17 \mathrm{e}-09$ & $0.242 * * *$ \\
\hline & $(4.38 \mathrm{e}-08)$ & $(9.93 \mathrm{e}-09)$ & $(7.34 \mathrm{e}-09)$ & $(0.0456)$ \\
\hline \multirow[t]{2}{*}{ M2BRATIO } & $3.21 \mathrm{e}-08^{* *}$ & $4.80 \mathrm{e}-09$ & $3.42 \mathrm{e}-09$ & $0.0809 * * *$ \\
\hline & $(1.34 \mathrm{e}-08)$ & $(3.04 \mathrm{e}-09)$ & $(2.25 \mathrm{e}-09)$ & $(0.0140)$ \\
\hline \multirow[t]{2}{*}{ RROR } & -0.00620 & -0.000384 & -0.00113 & $15.436^{* * *}$ \\
\hline & $(0.00839)$ & $(0.00190)$ & $(0.00141)$ & $(4.747)$ \\
\hline \multirow[t]{2}{*}{ BETA } & $15.50^{* *}$ & -0.343 & -1.671 & $3.408 \mathrm{e}+06$ \\
\hline & $(6.870)$ & (1.558) & $(1.152)$ & $(7.159 \mathrm{e}+06)$ \\
\hline \multirow[t]{2}{*}{ INF } & 0.549 & -0.228 & $0.252 *$ & $-446,085$ \\
\hline & $(0.860)$ & $(0.195)$ & $(0.144)$ & $(896,653)$ \\
\hline \multirow[t]{2}{*}{ DEBTRATIO } & 0.0355 & -0.00288 & $0.229 * * *$ & 45,357 \\
\hline & $(0.0613)$ & $(0.0139)$ & $(0.0103)$ & $(63,887)$ \\
\hline \multirow[t]{2}{*}{ LOGMVALUEOFEQUITY } & $-2.066^{*}$ & 0.0555 & -0.190 & $-700,750$ \\
\hline & $(1.046)$ & $(0.237)$ & $(0.175)$ & $(1.090 \mathrm{e}+06)$ \\
\hline \multirow[t]{2}{*}{ TA } & $-6.61 e-09$ & $3.83 \mathrm{e}-09$ & $-1.03 e-09$ & 0.0121 \\
\hline & $(9.36 \mathrm{e}-09)$ & $(2.12 \mathrm{e}-09)$ & $(1.57 \mathrm{e}-09)$ & $(0.00975)$ \\
\hline \multirow[t]{2}{*}{ TDEBT } & $2.95 \mathrm{e}-09$ & $-4.65 e-10$ & $5.11 \mathrm{e}-10$ & -0.622 \\
\hline & $(2.60 \mathrm{e}-09)$ & $(5.91 \mathrm{e}-10)$ & $(4.37 \mathrm{e}-10)$ & $(0.971)$ \\
\hline \multirow[t]{2}{*}{ Constant } & -3.760 & $7.207 * * *$ & $3.732 * * *$ & $2.642 \mathrm{e}+06$ \\
\hline & $(5.826)$ & $(1.321)$ & $(0.977)$ & $(6.070 \mathrm{e}+06)$ \\
\hline Observations & 49 & 49 & 49 & 49 \\
\hline R-squared & 0.524 & 0.796 & 0.955 & 0.907 \\
\hline
\end{tabular}

Standard errors in parentheses, $* * * \mathrm{p}<0.01, * * \mathrm{p}<0.05, * \mathrm{p}<0.1$

Table 10. Descriptive Statistics

\begin{tabular}{|c|c|c|c|c|c|}
\hline Variable & Obs & Mean & Std.Dev. & Min & Max \\
\hline FPCR & 62 & 1.276 & 1.398 & .338 & 6.377 \\
\hline ICR & 62 & 5.998 & 1.02 & 4.48 & 7.528 \\
\hline DIVIDENDPR & 69 & 1.861 & 1.014 & .5 & 4.33 \\
\hline INTERESTP & 63 & 248000 & 5.042 & 7316 & $2.12 \mathrm{e}+07$ \\
\hline SIZE & 61 & 3590000 & 8.510 & 4539 & $4.08 \mathrm{e}+07$ \\
\hline M2BRATIO & 69 & $1.65 \mathrm{e}+07$ & $4.02 \mathrm{e}+07$ & 45129 & $1.56 \mathrm{e}+08$ \\
\hline RROR & 70 & 6.436 & 13.288 & .17 & 72.24 \\
\hline BETA & 63 & .678 & .196 & .36 & 1.12 \\
\hline INF & 68 & 6.543 & .91 & 4.97 & 8.33 \\
\hline DEBTRATIO & 65 & 7.531 & 3.373 & 3 & 13 \\
\hline
\end{tabular}




\begin{tabular}{|c|c|c|c|c|c|}
\hline LOGMVALUEO $\sim$ Y & 68 & 4.327 & 1.029 & 3 & 6 \\
\hline TA & 69 & $2.60 \mathrm{e}+07$ & $5.78 \mathrm{e}+07$ & 93326 & $2.15 \mathrm{e}+08$ \\
\hline TDEBT & 69 & $1.92 \mathrm{e}+07$ & $2.82 \mathrm{e}+07$ & 125000 & $9.89 \mathrm{e}+07$ \\
\hline
\end{tabular}

For the business firms (Table 11), working in Singapore, effect through size on interest covered ratio and dividend payout ratio is significantly negative and significantly positive.

Table 11. Regression Findings for Manufacturing Firms in Singapore

\begin{tabular}{|c|c|c|c|c|}
\hline & $(1)$ & $(2)$ & $(3)$ & $(4)$ \\
\hline VARIABLES & FPCR:SINGAPORE & ICR:SINGAPORE & DPR:SINGAPORE & INTP:SINGAPORE \\
\hline SIZE & $-4.16 \mathrm{e}-08$ & $-6.54 \mathrm{e}-08^{* * *}$ & $2.15 \mathrm{e}-08^{* *}$ & 0.00653 \\
\hline & $(4.51 \mathrm{e}-08)$ & $(1.35 \mathrm{e}-08)$ & $(1.06 \mathrm{e}-08)$ & $(0.0669)$ \\
\hline M2BRATIO & $7.87 \mathrm{e}-08$ & $3.33 \mathrm{e}-09$ & $3.35 \mathrm{e}-08^{* *}$ & 0.100 \\
\hline & $(9.58 \mathrm{e}-08)$ & $(1.76 \mathrm{e}-08)$ & $(1.38 \mathrm{e}-08)$ & $(0.0869)$ \\
\hline RROR & -0.0112 & $0.0584 * *$ & -0.000955 & $-16,997$ \\
\hline & $(0.0404)$ & $(0.0223)$ & $(0.00277)$ & $(17,476)$ \\
\hline BETA & 7.345 & 1.446 & -1.917 & $4.524 \mathrm{e}+06$ \\
\hline & $(5.231)$ & $(2.638)$ & $(1.997)$ & $(1.262 \mathrm{e}+07)$ \\
\hline INF & $1.589^{*}$ & $1.275^{* * *}$ & -0.169 & $-976,994$ \\
\hline & $(0.933)$ & $(0.372)$ & $(0.268)$ & $(1.694 \mathrm{e}+06)$ \\
\hline DEBTRATIO & 0.0290 & -0.00467 & $0.242^{* * *}$ & 29,922 \\
\hline & $(0.0298)$ & $(0.0148)$ & $(0.0112)$ & $(70,586)$ \\
\hline LOGMVALUEOFEQUITY & -1.441 & -0.290 & -0.119 & $-794,665$ \\
\hline & $(0.944)$ & $(0.425)$ & $(0.318)$ & $(2.010 \mathrm{e}+06)$ \\
\hline TDEBT & $-3.66 \mathrm{e}-08$ & 1.94 & $-3.72 \mathrm{e}-09$ & 0.0320 \\
\hline & $(3.02 \mathrm{e}-08)$ & $(.8009)$ & $(4.55 \mathrm{e}-09)$ & $(0.0287)$ \\
\hline Constant & -7.789 & -2.115 & $3.003 *$ & $6.402 \mathrm{e}+06$ \\
\hline & $(5.170)$ & $(2.316)$ & $(1.703)$ & $(1.076 \mathrm{e}+07)$ \\
\hline & & & & 62 \\
\hline Observations & 68 & 62 & 68 & 0.031 \\
\hline R-squared & 0.676 & 0.432 & 0.354 & \\
\hline
\end{tabular}

Robust standard errors in parentheses, ${ }^{* * *} \mathrm{p}<0.01, * * \mathrm{p}<0.05, * \mathrm{p}<0.1$

While ROR has significantly positive influence on interest covered ratio. In addition, effect through inflation on fixed payment covered ratio and interest covered is significantly positive. Debt ratio indicates a coefficient of .242 and standard error of -.0112, significant at 1 percent. The rest of the factors have their insignificant impact on related factors of cost of capital.

\section{Conclusion}

This study has empirically examined the impact of size factor, required rate of return, market to book ratio, market value of equity, systematic risk, and total debt on cost of capital. For cost of capital, factors like fixed payment covered ratio, interest covered ratio, and overall interest payment, and dividend payout ratio are added in regression models. Overall five regions from ASEAN members have been selected while taking a sample of 10 firms, over last seven years. For business firms working in Brunei, effect of required return on interest covered ratio and dividend payout ratio is significantly negative. Debt ratio has its significantly positive influence on dividend payout. Log value of equity indicates a negative influence. Total debt has a significant but positive influence on ICR. For the firms working in Indonesia, significant determinant for fixed payment is size, and for both fixed payment and interest covered is market to book ratio. Effect of beta on interest payment is significantly 
negative. For the firms working in the region of Malaysia, debt ratio and market value of equity has its significant and positive (negative) effect on dividend payout ratio. Besides, size is found to be significantly determinant of interest payment as debt cost. For the firms, working in Thailand, size is found to be significant determinant of interest covered through EBIT and overall interest payment. Required rate of return found to be a significant determinant of interest payment. While debt ratio has its significant influence for DPR. For the firms, working in Singapore, effect on ICR and DPR is found to be significant through size factor. While market to book ratio is directly affecting the dividend payout. Besides inflation and debt ratio are significantly related to interest covered and dividend payout for the firms working in Singapore. These findings are providing a new insight in the literature of finance and financial management. Both theoretical and practical significance of the study can be viewed through provision of literature discussion and empirical findings. Policy makers, financial analysts, and other industry experts can utilize these findings as a meaningful source for strategic decision. However, future studies can be reconsidered remaining countries in ASEAN region and better sample size of the firms.

\section{References}

Anderson, R. C., Mansi, S. A., \& Reeb, D. M. (2003). Founding family ownership and the agency cost of debt. Journal of Financial economics, 68(2), 263-285. Available at: https://doi.org/10.1016/s0304-405x(03)00067-9

Anderson, R. C., Mansi, S. A., \& Reeb, D. M. (2004). Board characteristics, accounting report integrity, and the cost of debt. Journal of accounting and economics, 37(3), 315-342. Available at: https://doi.org/10.1016/j.jacceco.2004.01.004

Ali, I., \& Harvie, C. (2015). Oil Production Rehabilitation, Fiscal Policy and Economic Development in Libya: A Future View. Energy Economics Letters, 2(1), 1-23

Aregbeyen, O., \& Fasanyan, I. O. (2017). Oil price volatility and fiscal behaviour of government in Nigeria. Asian Journal of Economic Modeling, 5(2), 118-134.

Artha, I. W. B., \& Mulyana, B. (2018). The Effect of Internal and External Factors of Companies on Profitability and its Implications on Stock Price Index of State-Owned Banks. The Economics and Finance Letters, 5(2), 58-71.

Antoniou, C., Doukas, J. A., \& Subrahmanyam, A. (2015). Investor sentiment, beta, and the cost of equity capital. Management Science, 62(2), 347-367. Available at: https://doi.org/10.1287/mnsc.2014.2101

Arditti, F. D., \& Levy, H. (1977). The weighted average cost of capital as a cutoff rate: A critical analysis of the classical textbook weighted average. Financial Management, 6(3): 24-34. Available at: https://doi.org/10.2307/3665253

Abdulrasheed, B. (2017). Causality between government expenditure and government revenue in Nigeria. Asian Journal of Economics and Empirical Research, 4(2), 91-98.

Abosedra, S., \& Sita, B. (2018). Finance-Growth Volatility Nexus: Evidence from Lebanon. Asian Economic and Financial Review, 8(4), 466-477.

Adegbite, T. (2017). Personal Income Tax and Government Revenue: Evidence from Oyo State. International Journal of Social and Administrative Sciences, 2(2), 45-51.

Akhir, R. M., Ahmad, S. N. B., Ahmad, H., \& Hashim, N. A. (2018). Staying or Leaving? The Influence of Employees' Engagement towards Turnover Decision among Employees of A Semi-Government Organization in Malaysia. American Journal of Social Sciences and Humanities, 3(1), 55-62.

Aldulaimi, S. H., \& Abdeldayem, M. M. (2018). The Economic Value of Time in Arab Culture: New Evidence using Zimbardo Time Perspective Inventory (ZTPI). American Journal of Social Sciences and Humanities, 3(1), 63-72.

Bacidore, J. M., Boquist, J. A., Milbourn, T. T., \& Thakor, A. V. (1997). The search for the best financial performance measure. Financial Analysts Journal, 53(3), 11-20. Available at: https://doi.org/10.2469/faj.v53.n3.2081

Baker, M., \& Wurgler, J. (2015). Do strict capital requirements raise the cost of capital? Bank regulation, capital structure, and the lowrisk anomaly. American Economic Review, 105(5), 315-320. Available at: https://doi.org/10.1257/aer.p20151092

Belkhir, M., Saad, M., \& Samet, A. (2018). Stock extreme illiquidity and the cost of capital. Journal of Banking \& Finance.

Berger, P. G., Chen, H. J., \& Li, F. (2018). Firm specific information and the cost of equity capital. Feng, Firm Specific Information and the Cost of Equity Capital (April 2, 2018). 
Bevan, A. A., \& Danbolt, J. (2002). Capital structure and its determinants in the UK-a decompositional analysis. Applied Financial Economics, 12(3), 159-170. Available at: https://doi.org/10.1080/09603100110090073

Bontis, N. (2001). Assessing knowledge assets: a review of the models used to measure intellectual capital. International journal of management reviews, 3(1), 41-60. Available at: https://doi.org/10.1111/1468-2370.00053

Botosan, C. A. (1997). Disclosure level and the cost of equity capital. Accounting review, 323-349.

Botosan, C. A., \& Plumlee, M. A. (2002). A re-examination of disclosure level and the expected cost of equity capital. Journal of accounting research, 40(1), 21-40. Available at: https://doi.org/10.1111/1475-679x.00037

Boubakri, N., Guedhami, O., Mishra, D., \& Saffar, W. (2012). Political connections and the cost of equity capital. Journal of Corporate Finance, 18(3), 541-559. Available at: https://doi.org/10.1016/j.jcorpfin.2012.02.005

Boutayeba, F. (2017). Estimating the Returns to Education in Algeria. Asian Journal of Economic Modelling, 5(2), $147-153$.

Brown, E. D., \& Ibekwe, E. E. (2018). Effect of Institutional Factors on Foreign Direct Investment in Nigeria. The Economics and Finance Letters, 5(1), 12-27.

Cao, Y., Myers, L. A., Tsang, A., \& Yang, Y. G. (2017). Management forecasts and the cost of equity capital: international evidence. Review of Accounting Studies, 22(2), 791-838. Available at: https://doi.org/10.1007/s11142-017-9391-5

De Jong, A., Kabir, R., \& Nguyen, T. T. (2008). Capital structure around the world: The roles of firm-and country-specific determinants. Journal of Banking \& Finance, 32(9), 1954-1969. Available at: https://doi.org/10.1016/j.jbankfin.2007.12.034

Dhaliwal, D., Judd, J. S., Serfling, M., \& Shaikh, S. (2016). Customer concentration risk and the cost of equity capital. Journal of accounting and economics, 61(1), 23-48. Available at: https://doi.org/10.1016/j.jacceco.2015.03.005

Dhaliwal, D. S., Li, O. Z., Tsang, A., \& Yang, Y. G. (2011). Voluntary nonfinancial disclosure and the cost of equity capital: The initiation of corporate social responsibility reporting. The accounting review, 86(1), 59-100. Available at: https://doi.org/10.2308/accr.00000005

Drobetz, W., El Ghoul, S., Guedhami, O., \& Janzen, M. (2018). Policy uncertainty, investment, and the cost of capital. Journal of Financial Stability, 39, 28-45. Available at: https://doi.org/10.1016/j.jfs.2018.08.005

Flannery, M. J. (2016). Stabilizing large financial institutions with contingent capital certificates. Quarterly Journal of Finance, 6(02), 1650006. Available at: https://doi.org/10.1142/s2010139216500063

Foster, F. D., \& Kalev, P. S. (2016). Editorial to the special issue of the International Journal of Managerial Finance-Behavioral Finance. International Journal of Managerial Finance, 12(1). Available at: https://doi.org/10.1108/ijmf-10-2015-0186

Gertler, M. (1988). Financial structure and aggregate economic activity: an overview: National Bureau of Economic Research Cambridge, Mass., USA.

Gitman, L. J., Juchau, R., \& Flanagan, J. (2015). Principles of managerial finance: Pearson Higher Education AU.

Gupta, K., Krishnamurti, C., \& Tourani-Rad, A. (2018). Financial development, corporate governance and cost of equity capital. Journal of Contemporary Accounting \& Economics, 14(1), 65-82. Available at: https://doi.org/10.1016/j.jcae.2018.02.001

Haseeb, M., Hussain, H. I., Ślusarczyk, B., \& Jermsittiparsert, K. (2019). Industry 4.0: A solution towards technology challenges of sustainable business performance. Social Sciences, 8(5), 154.

Hail, L., \& Leuz, C. (2006). International differences in the cost of equity capital: Do legal institutions and securities regulation matter? Journal of accounting research, 44(3), 485-531. Available at: https://doi.org/10.1111/j.1475-679x.2006.00209.x

Herianingrum, S., Ratnasari, R. T., Widiastuti, T., Mawardi, I., Rachmi, R. C., Fadhlillah, H. (2019). The impact of Islamic bank financing on business, Entrepreneurship and Sustainability Issues, 7(1), 133-145. http://doi.org/10.9770/jesi.2019.7.1(11)

Huizinga, H., Voget, J., \& Wagner, W. (2012). Capital gains taxation and the cost of capital: evidence from unanticipated cross-border transfers of tax bases.

Hussain, H.I., Grabara, J., Razimi, M.S.A., \& Sharif, S.P. (2019) Sustainability of Leverage Levels in Response to Shocks in Equity Prices: Islamic Finance as a Socially Responsible Investment, Sustainability, 11, 3260.

Khan, M., \& Jain, P. (1992). Financial Management: Text and Cases: Tata McGraw Hill Publishing Company, New Delhi. 
Kwabi, F. O., Boateng, A., \& Adegbite, E. (2018). The impact of stringent insider trading laws and institutional quality on cost of capital. International Review of Financial Analysis, 60, 127-137. Available at: https://doi.org/10.1016/j.irfa.2018.07.011

Linsley, P. M., Shrives, P. J., \& Crumpton, M. (2006). Risk disclosure: An exploratory study of UK and Canadian banks. Journal of Banking Regulation, 7(3-4), 268-282. Available at: https://doi.org/10.1057/palgrave.jbr.2350032

Liu, M., \& Wysocki, P. (2017). Cross-sectional determinants of information quality proxies and cost of capital measures. Quarterly Journal of Finance, 7(02), 1650016. Available at: https://doi.org/10.1142/s2010139216500166

Masood, O., Tvaronavičienė, M., Javaria, K. (2019). Impact of oil prices on stock return: evidence from G7 countries. Insights into Regional Development, 1(2), 129-137. https://doi.org/10.9770/ird.2019.1.2(4)

Mazzi, F., André, P., Dionysiou, D., \& Tsalavoutas, I. (2017). Compliance with goodwill-related mandatory disclosure requirements and the cost of equity capital. Accounting and Business Research, 47(3), 268-312. Available at: https://doi.org/10.1080/00014788.2016.125 4593

Miles, J. A., \& Ezzell, J. R. (1980). The weighted average cost of capital, perfect capital markets, and project life: a clarification. Journal of financial and quantitative analysis, 15(3), 719-730. Available at: https://doi.org/10.2307/2330405

Miller, M., \& Modigliani, F. (1958). The cost of Capital. Corporate Finance and the Theory of Investment. American Economic Review, 48, 261-297.

Mira, M., Choong, Y., \& Thim, C. (2019). The effect of HRM practices and employees' job satisfaction on employee performance. Management Science Letters, 9(6), 771-786. http://dx.doi.org/10.5267/j.msl.2019.3.011

Mokhova, N., Zinecker, M., Meluzín, T. (2018). Internal factors influencing the cost of equity capital. Entrepreneurship and Sustainability Issues, 5(4), 827-845. http://doi.org/10.9770/jesi.2018.5.4(9)

Rajan, R. G., \& Zingales, L. (1995). What do we know about capital structure? Some evidence from international data. The journal of Finance, 50(5), 1421-1460. Available at: https://doi.org/10.2307/2329322

Rand, J. (2007). Credit constraints and determinants of the cost of capital in Vietnamese manufacturing. Small Business Economics, 29(12), 1-13. Available at: https://doi.org/10.1007/s11187-005-1161-2

Richardson, A. J., \& Welker, M. (2001). Social disclosure, financial disclosure and the cost of equity capital. Accounting, organizations and society, 26(7-8), 597-616. Available at: https://doi.org/10.1016/s0361-3682(01)00025-3

Sengupta, P. (1998). Corporate disclosure quality and the cost of debt. Accounting review, 459-474.

Schwarz, D. (2018). The ability of listed companies to optimize their capital structure, shape their distribution policy and fight hostile takeovers by repurchasing their own shares. Entrepreneurship and Sustainability Issues, 6(2), 636-648. https://doi.org/10.9770/ jesi.2018.6.2(12)

Siswanto, S., Supriyanto, A., Ni'mah, U., Asnawi, N., \& Wekke, I. (2019). Does a workload influence the performance of bank employees?. Management Science Letters, 9(5), 639-650. http://dx.doi.org/10.5267/j.ms1.2019.2.007

Van der Wijst, N., \& Thurik, R. (1993). Determinants of small firm debt ratios: An analysis of retail panel data. Small Business Economics, 5(1), 55-65. Available at: https://doi.org/10.1007/bf01539318 
Hafezali Iqbal HUSSAIN is an Associate Professor at Taylor's University. He received his Ph.D. in Finance from the University of Hull, UK. Formerly a chartered accountant at Citigroup, his work has appeared in several peer-reviewed finance, management and education journals and has presented at various conferences.

Orcid ID: orcid.org/0000-0002-9381-7743

HERMAN, SE., MM is the Lecturer of Management Departement of Economic Faculty Universitas Pakuan, Indonesia. Work has attracted research paper in Indonesia. Research interests: Organization culture, Organizational Behaviour, Empowerement, entrepreneurship and regional development; innovation and small firms; Micro, Small and Medium Enterprise (MSMEs).

Erlane K GHANI, PhD, CPA, CA(M) is an Associate Professor from Universiti Teknologi MARA. She teaches various accounting related subjects from Diploma to Masters level. She has embarked into research since 1999 with several international and local grants. Erlane has also published extensively. In addition, she has also provided consultancy projects to government and local institutions. Her research area interests include financial reporting and accounting education.

Mohd Shahril Ahmad RAZIMI is a Senior Lecturer in the Islamic Business School at Universiti Utara Malaysia. He teaches management, finance, Islamic management and education. His research interests are in the area of management, finance and Islamic management principles. In addition, he has also completed several consultation projects with governmental and private bodies.

This work is licensed under the Creative Commons Attribution International License (CC BY). http://creativecommons.org/licenses/by/4.0/ 